\title{
Civilian Employment Among Wives of US Army Soldiers: Results from the 2001 Survey of Army Families
}

\author{
Walter R Schumm ${ }^{1 *}$, David Bruce Bell², Richard J Fafara ${ }^{3}$ and Susan EW Curry ${ }^{1}$ \\ ${ }^{1}$ Kansas State University, Kansas, United States \\ ${ }^{2}$ U.S. Army Research Institute for the Behavioral and Social Sciences, United States \\ ${ }^{3}$ U.S. Army Community and Family Support Center, United States
}

Submission: December 15, 2018; Published: February 06, 2019

*Corresponding author: Walter R Schumm, School of Family Studies and Human Services, Kansas State University, 1700 Anderson Avenue, Manhattan, KS, United States

\begin{abstract}
In the Spring of 2001, over seven thousand Army spouses were surveyed as part of the fourth Survey of Army Families. Data from a subsample of civilian wives living with their soldier husbands in the United States were assessed for several outcomes related to level and desired level of spouse employment. Higher labor force participation was significantly related to having a college degree, not having preschool children, longer residence at current installation, higher rank if the soldier was a noncommissioned officer, and African-American racial background. Lower involuntary unemployment was associated with European-American racial background, having a college education, longer residence at current installation, commissioned officer rank, and not having younger children at home. Voluntary homemaker status was associated with EuropeanAmerican and Hispanic ethnic background, commissioned officer rank, having preschool or elementary school-aged children at home, and not having a college education. With respect to six outcome measures concerning satisfaction with personal life, marriage, and the military way of life, satisfaction was consistently higher for homemakers and labor force participants and lower for those looking for or otherwise unable to find paid employment. Interestingly, homemaker spouses of commissioned officers reported the strongest retention intentions, although at the same time, enlisted members' spouses who were employed full-time reported retention intentions at least as strong as similarly employed spouses of commissioned officers. Satisfaction with employment and career opportunities for wives and with availability of affordable daycare were found to be correlated with favorable military outcomes.
\end{abstract}

\section{Introduction}

It is well known that the demography of U. S. families has been changing [1]. Wives' employment is associated with families having higher incomes and has been increasing, even for mothers with young children [2-4]. Median income for U. S. families without an employed mother declined from 1980 to 1998 [5]. Maternal employment is associated with positive mental health outcomes and parenting outcomes, especially if mothers want to work outside the home [6]. Maternal contributions to family income can enhance the quality of family life. However, many mothers experience high levels of stress with employment, especially if they have younger children and fewer resources, such as ready access to high quality daycare $[2,6]$. Family income appears to have an indirect effect on marital happiness by operating through the reduction of financial worry and stress, even if it does not have much of a direct impact on marital happiness by itself $[5,7]$.

Work stress appears to influence marital relations through the intervening variables of depression, sense of overload, and personal distress [3]. Work stressors can manifest themselves in many areas, including lower job satisfaction, self-esteem, marital satisfaction, and job aspirations [8], as well as overall quality of life [6] and turnover or retention and job performance [9]. It appears that work is more likely to interfere with the quality of family life (work/family conflict) than for family pressures to interfere with work responsibilities and that work family conflict "bears stronger negative relationships with job satisfaction and life satisfaction than does family/work conflict [6]." 
Ultimately, “The quality of fit between an individual's work and family life is a primary issue for families today.... [10]. Such issues are relevant to military families [11] as well as to civilian families. Russo, et al. [12] note that "Today, spouse employment is recognized as an important quality-of-life issue for the Department of Defense." Pittman [13] argues that research with military families is an ideal place to study issues of work/ family fit. Segal [14] saw military families as a prime example of an arena of conflict between two institutions greedy for an individual's time. Because of the additional demand's frequent moves, family separations, long and unpredictable work hours for the service member, living in rural or overseas locations with few work opportunities, that military service places on the spouses of servicemembers, finding and keeping a career (even a job) can be challenging for military spouses [12].

Bowen [15] developed a model in which characteristics of the military member's job ultimately influenced the marital satisfaction, satisfaction with military life, spouse support for member's career, and retention intentions of both the military member and his or her spouse. Earlier Bowen [16] had found that employment among Air Force officers' wives was dysfunctional to their marriages. However, Pittman [13] found no relationship between a wife's employment status and her view of work/family fit, her marital tension, or her satisfaction with her military husband's work hours, using data from 407 Army couples; however, he did find that employed wives were more secure with respect to their total family income. Likewise, Sebenick [17] found that the employment status of wives married to U. S. military officers was not directly related to their overall psychological well-being, although higher total family income did predict higher well-being. Russo et al. [12] proposed a model in which spouse employment influenced spouse support for the soldier, which influenced the soldier's satisfaction with military life, which then influenced his retention. Hoffman [4] summarizes previous research by noting that employed mothers generally report higher well-being and mental health. However, congruence of work status and desired work role has been related to higher levels of well-being, although the consequences of different types of incongruence may be different.

Russo et al. [12] in their review of the literature on military wives' employment found four factors to be associated with level of spouse labor force participation - higher civilian education, higher soldier's rank, longer time at the current duty station, and the presence of children, notably preschool children, which was associated with a reduction in paid employment. Race was associated with underemployment in their review.

\section{Objectives}

The first objective of the study was to reassess Russo et al. [12] hypotheses regarding education, rank, time at duty station, children, and race on civilian spouse employment. Would those factors predict levels of employment and congruence of current status with desired level of employment? The second objective of the study was to assess the relationship of employment status with six outcome variables of interest, including personal life satisfaction, own marital satisfaction, satisfaction with the Army's concern for families, perceived level of family adjustment to the demands of being an "Army" family, overall satisfaction with life in the Army, and spouse's personal intentions regarding the soldier's remaining in the Army. A third objective was to predict, simultaneously, the same six outcome variables from employment status and the five factors (education, rank, race, etc.) previously used to predict employment status, to determine if any effects of employment status were merely artifacts of the other five factors or if employment status had any unique association with the six outcome variables that was independent of the five factors. Finally, we examined the apparent effectiveness of some of the Army's programs designed to support spouse employment.

\section{Method}

\section{Samples}

The Survey of Army Families IV was conducted by the Army Personnel Survey Office of the U.S. Army Research Institute for the Behavioral and Social Sciences (Alexandria, Virginia) in the spring of 2001 under the sponsorship of the U.S. Army Community and Family Support Center. It represents a stratified random sample of civilian spouses of active duty Army servicemembers from across the world. Dual military married couples and single parents were not eligible for this survey. Data were weighted by rank, race, and other variables to approximate the true demographic composition of all Army civilian spouses. The response rate is estimated to have been approximately $33 \%$. While useable data were obtained from 6,759 spouses who responded to the survey, data used here include only 4,255 spouses, weighted up to 153,725 cases. Responses of spouses who were not living with their soldier, who were living outside the continental United States, and male spouses were not included in order to restrict the analysis to female civilian spouses living with soldiers stationed in the continental United States. Our objective was to narrow the sample so that it would correspond as closely as possible to research on maternal employment conducted with civilian samples within the United States. In addition, we did not include wives married to warrant officers in order to make the assessment of rank clearer (the ages and salaries of warrant officers often differ considerably from their commissioned peers) and because their group constituted such a small proportion of the data as to make some of our multivariate analyses much more difficult, if not impossible. Demographic data for the sample, for weighted and unweighted data, are presented in Table 1. 


\section{Psychology and Behavioral Science International Journal}

Table 1: Demographic Characteristics.

\begin{tabular}{|c|c|c|c|}
\hline Variables & Characteristics & Unweighted Data & Weighted Data \\
\hline NA & Sample Size (N) & 4,255 & 153,725 \\
\hline \multirow{4}{*}{ Age of Wife (years) } & Mean & 34.4 & 31.0 \\
\hline & Median & 34.0 & 30.0 \\
\hline & SD & 8.6 & 7.6 \\
\hline & Range & $17-66$ & $17-66$ \\
\hline \multirow{4}{*}{ Duration of marriage (years) } & Mean & 11.1 & 8.4 \\
\hline & Median & 10.0 & 7.0 \\
\hline & SD & 8.2 & 6.5 \\
\hline & Range & $0-45$ & $0-45$ \\
\hline \multirow{4}{*}{ Total Number of Children } & Mean & 1.5 & 1.5 \\
\hline & Median & 2.0 & 2.0 \\
\hline & SD & 1.2 & 1.1 \\
\hline & Range & $0-7$ & $0-7$ \\
\hline \multirow{3}{*}{ Marital Status } & First Marriage & $86.9 \%$ & $84.1 \%$ \\
\hline & Remarried, was divorced & $12.8 \%$ & $15.6 \%$ \\
\hline & Remarried, was widowed & $0.3 \%$ & $0.3 \%$ \\
\hline \multirow{5}{*}{ Current Employment Status } & Full-time & $29.30 \%$ & $28.80 \%$ \\
\hline & Part-time & $18.90 \%$ & $18.30 \%$ \\
\hline & Looking & $7.80 \%$ & $10.10 \%$ \\
\hline & Not Looking & $10.40 \%$ & $13.60 \%$ \\
\hline & Homemaker & $33.60 \%$ & $29.20 \%$ \\
\hline \multirow{5}{*}{ Rank of Soldier } & Junior Enlisted & $10.90 \%$ & $25.90 \%$ \\
\hline & Junior NCO & $12.00 \%$ & $36.50 \%$ \\
\hline & Senior NCO & $18.00 \%$ & $18.10 \%$ \\
\hline & Junior Officer & $28.60 \%$ & $9.10 \%$ \\
\hline & Senior Officer & $30.50 \%$ & $0.30 \%$ \\
\hline \multirow{4}{*}{ Racial/Ethnic Heritage } & Caucasian & $77.30 \%$ & $71.40 \%$ \\
\hline & Black & $8.40 \%$ & $10.40 \%$ \\
\hline & Other Minority & $6.20 \%$ & $7.00 \%$ \\
\hline & Hispanic & $8.10 \%$ & $11.20 \%$ \\
\hline \multirow{7}{*}{ Education } & Less than High School & $1.6 \%$ & $3.0 \%$ \\
\hline & High School & $16.6 \%$ & $27.2 \%$ \\
\hline & Some Votech/College & $35.7 \%$ & $45.9 \%$ \\
\hline & B.A./B.S. Degree & $28.7 \%$ & $16.6 \%$ \\
\hline & Some Graduate Study & $5.4 \%$ & $2.3 \%$ \\
\hline & M.A./M.S. Degree & $10.0 \%$ & $4.3 \%$ \\
\hline & Doctoral Degree & $1.8 \%$ & $0.7 \%$ \\
\hline \multirow{4}{*}{ Family Life Cycle } & Newlyweds, no children & $18.1 \%$ & $18.8 \%$ \\
\hline & Preschool Children & $40.3 \%$ & $50.0 \%$ \\
\hline & Elementary School Age Children & $21.3 \%$ & $20.5 \%$ \\
\hline & $\begin{array}{l}\text { Older Children/Never Had } \\
\text { Children }\end{array}$ & $20.2 \%$ & $10.6 \%$ \\
\hline \multirow{3}{*}{ Months at Current Duty Station } & Less than 13 & $36.8 \%$ & $35.2 \%$ \\
\hline & $13-48$ & $50.2 \%$ & $51.4 \%$ \\
\hline & More than 48 & $12.9 \%$ & $13.4 \%$ \\
\hline
\end{tabular}




\section{Measures}

Employment status was measured by a single item that asked wives to specify if they were currently employed full-time, part-time or not employed. Those who were not employed were asked to indicate if

a. They were looking for paid employment,

b. Wanted a paid job but were not looking,

c. Were not employed, not looking, and did not want a paid job at the present time (they might well have had paid work in the past or may well decide to seek paid employment in the future).

It is important to explain that at some military installations there are either no jobs or relatively few jobs available for spouses; therefore, some spouses who want jobs see no reason to waste time looking for what they probably won't be able to find. Initially, our goal was to assess a lack of congruence between current employment status and aspirations as true for those looking for employment or who were not looking but wanted a paid job. Congruence was assumed to be true for those employed full-time or part-time or who were not employed, not looking, and who didn't want a paid job now (the latter group identified for brevity's sake as "homemakers."). However, from another question we determined that seven spouses were working parttime who said they did not want to be working at all for pay, but their responses were such a small proportion of the sample that they were ignored for purposes of the analyses here. Since "employment incongruence" was primarily associated with seeking employment (and not finding it) that we relabeled the concept as simply (involuntary) "Unemployment."

Educational attainment was measured by a single item that initially included twelve categories but those were recoded into seven levels and in some of analyses into only two levels (college degree or more versus less than a college degree). Race was measured for the spouse as Caucasian, Black, Hispanic, or Other (American Indian, Alaska Native, Asian, Native Hawaiian or other Pacific Islander), although in some analyses we found it convenient to code race as Black or Other (combining Caucasian, Hispanic, and Other groups). Family life cycle was created with four levels - newlyweds (those married ten years or less with no children), marrieds whose youngest children were of preschool age, marrieds who youngest children were of elementary school age, and marrieds whose youngest children were teenagers or older or married couples with no children who had been married for over ten years. Years at present duty station was initially measured in five levels but we collapsed the levels into three: less than 13 months, 13 to 48 months, and more than 48 months. Rank was collapsed in some analyses from five levels (E1-E4; E5-E6; E7-E9; 01-03; 04-06) into three levels - junior enlisted personnel (paygrades of E-1 to E-4), noncommissioned officers (paygrades of E-5 to E-9), and commissioned officers (paygrades of 0-1 to 0-6).
Personal life satisfaction was measured by an item that asked, "How satisfied are you with the way things are going for you personally?" with three responses used, of "very satisfied," "more or less satisfied," and "not at all satisfied." Fewer than one percent of spouses replied "Do not know" but their responses were treated as missing data. Marital satisfaction was measured by an item that asked, "How satisfied are you with your marriage at the present time?" with eleven possible responses benchmarked by the terms "very satisfied" and "very dissatisfied." Personal retention intention was assessed by an item that asked, "At the present time, what would you like your spouse's Army career plans to be? Responses included, "to stay in the Army until retirement," "To stay in the Army beyond his present obligation, but not necessarily to retirement," "to leave the Army upon completion of his present obligation," and "to leave the Army before completion of his present obligation."

Family adjustment was measured by an item that asked, "In general, how well as your family adjusted to the demands of being an "Army family"?" Responses ranged from "extremely well" to "extremely badly" in eleven levels. Satisfaction with perceived Army family support was measured by an item, "How satisfied are you with the support and concern the Army has for your family?" Satisfaction with Army life was measured by, "Overall, how satisfied are you with the Army as a way of life?" Both last two items had five possible response categories - very satisfied, satisfied, neutral, dissatisfied, and very dissatisfied. We also used a scale for Army Concern for Families, summing "How satisfied are you with the support and concern the Army has for your family" with "How satisfied are you with the concern your spouse's unit has for families" and "How satisfied are you with the respect the Army shows spouses." The three-item scale yielded a Cronbach alpha of 0.82 , a range of 3 to 15 points, and an average of $9.32(\mathrm{SD}=2.82)$.

\section{Analyses}

In order to maximize generalizability to the Army as a whole (for those civilian wives living with male soldiers in the continental United States, less warrant officers' spouses), data were weighted to represent all spouses. As a result, almost all statistical tests yielded significant values. Consequently, our focus was on the strength of associations rather than their significance levels, with more attention given to crosstabulation results than more complex statistics.

Most of our analyses used the chi-square test because our primary variable, employment status, was a nominal variable. We also used binary logistic regression when predicting labor force participation, full-time employment, homemaker status, and unemployment from dummy variables coded to capture race, rank, family life cycle, months at installation, and education. We used one-way analyses of variance to predict our six outcome variables from employment status as an independent variable. Analysis of variance predicting six outcome variables from employment status and five other factors (race, rank, family life 
cycle, months at installation, and education) as independent variables was used to assess the ability of employment status to explain unique variance in outcomes after controlling for the other five variables.

\section{Results}

\section{Predicting Employment Status: Bivariate Results}

Table 2 shows the association between spouse's educational attainment and their current employment status. In general, homemaker status declined with higher levels of education, from nearly $51 \%$ for those with less than a high school education to $23 \%$ for those with a doctoral degree. Labor force participation generally increased with higher education, from 19\% for those with less than a high school degree to $58 \%$ for most of those with a college degree or higher. At the same time, unemployment tended to decrease with higher education, from over 30\% for those with a high school degree or less to between 10 and $18 \%$ for those with a college degree of higher. Having attained a college degree appeared to mark some of the important shifts in the association between education and employment. While the percent of spouses looking for work declined consistently with higher education, wanting work but no longer looking for it varied, as wives with doctoral degrees reported higher levels than those with less graduate education. That shift may have reflected very highly educated wives if there were not enough jobs near Army installations for wives of their educational level.

Table 2: Wives' Employment and Educational Attainment.

\begin{tabular}{|c|c|c|c|c|c|}
\hline \multirow{2}{*}{ Educational Attainment } & \multicolumn{5}{|c|}{ Employment Status } \\
\hline & Full-Time & Part-Time & Looking for Work & Not Looking & Homemaker \\
\hline Less Than High School & 9.6 & 9.4 & 12.4 & 17.8 & 50.9 \\
\hline High School & 23.1 & 18.6 & 14.2 & 18.9 & 25.2 \\
\hline Post-High School Training & 27 & 19.1 & 9.5 & 13.9 & 30.5 \\
\hline College Degree & 40.7 & 17.6 & 7.1 & 6.8 & 27.8 \\
\hline Some Graduate Study & 40.5 & 17.2 & 7.5 & 8.5 & 26.3 \\
\hline Master's Degree & 38.8 & 17.2 & 6.3 & 3.9 & 33.8 \\
\hline Doctoral Degree & 38.4 & 20.4 & 4.4 & 13.5 & 23.2 \\
\hline
\end{tabular}

Lambda $=.040, \mathrm{Phi}=.223$, Cramer's V $=.111$, Contingency coefficient $=.217(p<.001)$ Chi-square $(24)=7,346.1(p<.001)$.

Note: Percentages sum across each educational level (row) to approximately 100 percent. Lambda assessed with employment status as dependent variable.

Family life cycle appeared to play an important role with respect to employment status., as shown in Table 3. Homemaker status was nearly twice as frequent for families with preschool children compared to any other stage of the family life cycle. At

Table 3: Wives' employment and family life cycle status.

\begin{tabular}{|c|c|c|c|c|c|}
\hline \multirow{2}{*}{ Family Life Cycle } & \multicolumn{5}{|c|}{ Employment Status } \\
\cline { 2 - 7 } & Full-Time & Part-Time & Looking for Work & Not Looking & Homemaker \\
\hline Newlywed & 42.9 & 22 & 9.9 & 10.6 & 14.5 \\
\hline Preschool & 16.9 & 13.7 & 10.9 & 17.9 & 40.6 \\
\hline Elementary & 33 & 25.8 & 9.9 & 5.1 & 20.7 \\
\hline Older & 50.6 & 19.4 & 7.2 & 17.8 \\
\hline
\end{tabular}

Lambda $=.160$, Phi $=.363$, Cramer's V = .210, Contingency coefficient $=.342(p<.001)$ Chi-square $(12)=19,933.4(p<.001)$.

Note: Percentages sum across each educational level (row) to approximately 100 percent. Lambda assessed using employment status as dependent variable.

While homemaker status did not vary much with duration of time at duty station, labor force participation tended to increase the longer the spouse had been at the same location, rising from $36 \%$ to $64 \%$. Unemployment decreased with duration of time at duty station, from $34 \%$ to $11 \%$, as shown in Table 4 . As shown in Table 5, rank was associated with employment status. the same time, unemployment was also highest, nearly $30 \%$, for families with preschool children. Labor force participation was also lowest for families with preschool children (31\%) compared to the other stages that range from $55 \%$ to $70 \%$.
Homemaker status was mainly associated with officers' wives. Labor force participation was highest (63\%) for the wives of senior noncommissioned officers and lowest (38\%) for the wives of junior enlisted personnel. Unemployment was lowest (12\%) for wives of officers and highest (36\%) for wives of junior enlisted personnel. 


\section{Psychology and Behavioral Science International Journal}

Table 4: Wives' Employment and Duration of Time at Current Duty Station.

\begin{tabular}{|c|c|c|c|c|c|}
\hline \multirow{2}{*}{ Time at Duty Station } & \multicolumn{5}{|c|}{ Employment Status } \\
\cline { 2 - 6 } & Full-Time & Part-Time & Looking for Work & Not Looking & Homemaker \\
\hline Less Than 13 Months & 21.9 & 14.4 & 17.1 & 12.7 & 29.4 \\
\hline $13-48$ Months & 28.4 & 21.6 & 7.0 & 7.1 & 24.6 \\
\hline Over 48 Months & 48.8 & 15.4 & 4.1 & \\
\hline
\end{tabular}

Lambda $=.046, \mathrm{Phi}=.259$, Cramer's $V=.183$, Contingency coefficient $=.251(p<.001)$ Chi-square $(8)=10,149.9(p<.001)$.

Note: Percentages sum across each educational level (row) to approximately 100 percent. Lambda assessed using employment status as dependent variable.

Table 5: Wives' Employment and Soldier's Military Rank.

\begin{tabular}{|c|c|c|c|c|c|}
\hline \multicolumn{7}{|c|}{ Employment Status } \\
\hline Military Rank & Full-Time & Part-Time & Looking for Work & Not Looking & Homemaker \\
\hline Junior Enlisted (E1-E4) & 21.1 & 16.7 & 16.2 & 19.7 & 26.4 \\
\hline Mid-Level NCOs (E5-E6) & 29.8 & 18.0 & 9.6 & 14.1 & 28.4 \\
\hline Senior NCOs (E7-E9) & 42.6 & 19.9 & 8.3 & 8.6 & 19.6 \\
\hline Junior Officers (01-03) & 26.8 & 14.7 & 6.4 & 8.1 & 43.4 \\
\hline Senior Officers (04-06) & 22.1 & 23.6 & 3.5 & 42.7 \\
\hline
\end{tabular}

Lambda $=.066$, Phi $=.265$, Cramer's V $=.132$, Contingency coefficient $=.256(p<.001)$ Chi-square $(16)=10,671.8(p<.001)$.

Note: Percentages sum across each educational level (row) to approximately 100 percent. Lambda assessed using employment status as dependent variable.

In Table 6, results were remarkably similar for all racial and ethnic groups except for Black spouses. Black spouses reported higher levels of labor force participation (63\%), the lowest levels of homemaker status (7\%), and nearly the highest levels

of unemployment (30\%) despite their high levels of labor force participation. Clearly, data from Black spouses represented a different pattern than that observed for other racial/ethnic groups.

Table 6: Wives' Employment and Their Racial/Ethnic Background.

\begin{tabular}{|c|c|c|c|c|c|}
\hline \multirow{2}{*}{ Race/Ethnicity } & \multicolumn{5}{|c|}{ Employment Status } \\
\cline { 2 - 6 } & Full-Time & Part-Time & Looking for Work & Not Looking & Homemaker \\
\hline European-American & 28 & 17.8 & 9.1 & 12.7 & 32.4 \\
\hline African-American & 40 & 23.1 & 13.9 & 16.1 & 7 \\
\hline Hispanic & 23.4 & 18.2 & 12.3 & 11.4 & 32.9 \\
\hline Other & 26.9 & 16.1 & 13.3 & & 32.2 \\
\hline
\end{tabular}

Lambda $=.048, \mathrm{Phi}=.184$, Cramer's V $=.106$, Contingency coefficient $=.181(p<.001)$ Chi-square $(12)=5,065.5(p<.001)$

Note: Percentages sum across each educational level (row) to approximately 100 percent. Lambda assessed using employment status as dependent variable.

\section{Predicting Employment Status: Multivariate Results}

Binary logistic regression analyses were used to predict labor force participation, full-time employment, homemaker status, and unemployment from all our independent variables, recoded into dummy variables in order to capture the effects of each level of each independent variable. Odds ratios and model outcomes are presented in Table 7. Analysis of variance was used to assess all possible two-way interaction effects. Higher labor force participation was significantly related to having a college degree, not having preschool children, longer residence at current installation, higher rank if the soldier was a noncommissioned officer, and African-American racial background. Lower involuntary unemployment was associated with EuropeanAmerican racial background, having a college education, longer residence at current installation, commissioned officer rank, and not having younger children at home. Voluntary homemaker status was associated with European-American and Hispanic ethnic background, commissioned officer rank, having preschool or elementary school-aged children at home, and not having a college education. 


\section{Psychology and Behavioral Science International Journal}

Table 7: Odds Ratios Using Binary Logistic Regression to Predict Employment Statuses from Race, Rank, Family Life Cycle, Months at Installation, And Education.

\begin{tabular}{|c|c|c|c|c|}
\hline \multicolumn{5}{|c|}{ Employment Status } \\
\hline Variables & In Labor Force & Full-Time & Homemaker & Has Desired Status vs. Looking for/Wanting Job \\
\hline \multicolumn{5}{|c|}{ Race (versus Other) } \\
\hline European-American & 1.37 & 1.25 & 0.93 & 1.37 \\
\hline African-American & 2.84 & 2.21 & 0.12 & 0.81 \\
\hline Hispanic & 1.30 & 0.98 & 0.77 & 1.07 \\
\hline \multicolumn{5}{|c|}{ Rank (versus NCO) } \\
\hline Junior Enlisted & 0.76 & 0.72 & 0.86 & 0.67 \\
\hline Officer & 0.44 & 0.34 & 3.33 & 1.51 \\
\hline \multicolumn{5}{|c|}{ Family Life Cycle (versus Older Stage) } \\
\hline Newlyweds & 1.03 & 0.93 & 0.91 & 0.86 \\
\hline Preschool & 0.21 & 0.22 & 4.08 & 0.52 \\
\hline Elementary & 0.59 & 0.43 & 1.45 & 0.63 \\
\hline \multicolumn{5}{|c|}{ Months at Installation (versus 13-48 Months) } \\
\hline Less Than 13 Months & 0.54 & 0.71 & 0.89 & 0.44 \\
\hline More Than 48 Months & 1.44 & 2.17 & 0.93 & 1.68 \\
\hline \multicolumn{5}{|c|}{ Education } \\
\hline Has College Education & 2.70 & 3.33 & 0.49 & 1.82 \\
\hline \multicolumn{5}{|l|}{ Education } \\
\hline -2 Log Likelihood & 173435.1 & 149954.0 & 155025.2 & 146572.2 \\
\hline Nagelkerke R-squared & 0.224 & 0.209 & 0.187 & 0.128 \\
\hline \multicolumn{5}{|c|}{ Hosmer and Lemeshow } \\
\hline Goodness of Fit & 638.5 & 184.0 & 1023.2 & 901.5 \\
\hline \multicolumn{5}{|l|}{ Chi-square Test } \\
\hline DF & 8 & 8 & 8 & 8 \\
\hline $\mathrm{p}$ & $<.0001$ & $<.0001$ & $<.0001$ & $<.0001$ \\
\hline Percent Correctly Classified & 68.6 & 74.7 & 72.9 & 76.4 \\
\hline
\end{tabular}

Note: Odds ratios between 0.98 and 1.06 were not significant $(p<.05)$.

\section{Observed Interaction Effects - Full-time Employment}

Several interaction effects were significant and accounted for substantial portions of variance relative to main effects. Family life cycle interacted with education and with years at duty station to predict full-time employment. Previously, we have noted how employment levels were lower for families with preschool children. That pattern holds, regardless of educational level, across the life cycle except for the newlywed stage, where $33 \%$ of those with less than a college degree report full-time employment compared to $69 \%$ with a college degree. With respect to time at duty station and family life cycle, the main effects hold (lower for preschool families, higher with more years) except for those whose youngest children are teenagers or older and have been at their duty station for more than 4 years $68 \%$ of those wives report full-time employment, far more than any other group (56\% being the next highest, newlyweds with more than 4 years). An interaction between rank and years at duty station is related to little change with years for enlisted personnel's' wives, for whom full-time employment rises from
$21 \%$ to $28 \%$, compared to major changes for NCOs (25\% to $52 \%$ ) and officers (19\% to $41 \%$ ) with more years at the same duty station. An interesting interaction between rank and education was observed, with highly educated wives of junior enlisted and NCOs reporting $62 \%$ and $55 \%$ full-time employment, respectively, compared to between $18 \%$ and $30 \%$, respectively, for wives without college educations. An interaction was also noted for years at duty station and race, as full-time employment increased from $22 \%$ to $46 \%$ over time for whites compared to an increase from $31 \%$ to $73 \%$ for black wives. The lowest overall level of full-time employment $(10 \%)$ was observed for wives of officers with preschool children; the highest rate observed (73\%) was for black wives who had been at their current duty station for over four years.

\section{Labor Force Participation}

Family life cycle interacted substantially with three other variables, including education, years at duty station, and rank with respect to predicting labor force participation. The 
largest difference on education over the life cycle occurred for newlyweds ( $57 \%$ versus $86 \%$ ), where $86 \%$ was the highest level of labor force participation of any subgroup in this analysis. At the other stages of the family life cycle, the difference in education accounted for no more than between $5 \%$ and $12 \%$ difference in labor force participation, though it was always higher for those with a college degree or more. In terms of the interaction with years at duty station, there is relatively little change for newlyweds (57\% to $71 \%$ ) or the oldest group (69\% to $79 \%$ ) in labor force participation as a function of years at duty station, though it increases with years. The changes are much greater for those with preschool children (22\% to $48 \%$ ) or elementary school age children (40\% to $68 \%$ ). Those with preschool children who have just arrived at their duty station have, by far, the lowest levels of labor force participation (22\%) of any group.

In terms of the family life cycle and rank, we found that labor force participation levels were uniformly high at both ends of the life cycle, regardless of rank - $61 \%$ to $69 \%$ for newlyweds and $56 \%$ to $75 \%$ for those whose youngest children were teenagers. However, for those with preschool or elementary school aged children, labor force participation levels were highest for NCOs' wives (35\% and 64\%) and lowest for wives of junior enlisted personnel (26\% and 27\%). With respect to rank and years at duty station, we found that years made little difference for wives of junior enlisted personnel, as labor force participation ranged between only $35 \%$ and $42 \%$. In contrast, for wives of NCOs and officers, the highest levels of labor force participation were observed when they had lived at their current duty station for over 4 years (67\% and $60 \%$ ). Overall, the lowest level of labor force participation (22\%) was observed for wives with preschool children who had lived at the duty station for less than 13 months. The highest levels of labor force participation (86\%) were observed for newlyweds with a college degree or higher.

\section{Unemployment}

A number of substantial interactions were observed for employment congruence, mostly with family life cycle and other factors. With respect to education and the life cycle, we observed an increase in similarity of congruence at the later two stages, where differences were small $(10 \%$ and $2 \%)$ compared to the newlywed stage $(75 \%$ versus $91 \%)$ and the preschool stage (68\% versus $84 \%$ ). In other words, those with less than a college degree seemed to have more difficulty finding the work status they desired during the first two or three stages of the family life cycle compared to those with higher educational attainment. With respect to years at duty station and family life cycle, years made the most difference for those with preschool children (62\% to $90 \%$ ) compared to the other three stages where differences ranged from $8 \%$ to $20 \%$. In other words, having preschool children didn't seem to be a barrier to attaining one's desired employment status, if one had been at the duty station for a longer time. However, for those with preschool children the shift took time $(62 \%$ to $75 \%$ from initial year at installation to
13-48 months, $90 \%$ for over 48 months at installation) whereas newlyweds gained quickly ( $67 \%$ to $89 \%$ from first year to $13-48$ months; $86 \%$ for over 48 months) as did those with elementary school aged children (67\% to $88 \%$ from first year to $13-48$ months). Those whose teenagers were their youngest children were relatively successful at finding their desired employment (83\% compared with $87-92 \%$ at later years) within the first year at their duty station.

The rank with family life cycle interaction was instructive. Most of the wives of officers (85\% to $89 \%$ ) and NCOs (72\% to $88 \%$ ) found their desired employment status no matter what their stage of the family life cycle. In contrast, the newlywed wives of junior enlisted reported moderate levels of congruence $(72 \%)$ while at later stages the percentages were lower $(50 \%$ to $68 \%$ ). In other words, a center of incongruence appeared to be located with mothers, married to junior enlisted soldiers. Another such locus was Black wives with preschool children (54\%) compared to a range of $73 \%$ (Non-black wives with preschool children) to $92 \%$ (Black newlywed wives) for all other combinations of race and life cycle. Years at duty station also interacted with race. For Black wives, congruence employment status increased from $53 \%$ to $85 \%$ with years at duty station, compared to a change from $67 \%$ to $89 \%$ for non-black wives. Rank interacted with education inasmuch as wives of officers were able to achieve their desired employment status regardless of their education ( $84 \%$ versus $88 \%$ ) in contrast to wives of junior enlisted personnel (63\% versus 75\%) and NCOs (77\% versus $87 \%$ ) for whom education made a greater difference. In terms of rank and years at duty station, again, years made less difference for the wives of officers ( $82 \%$ to $90 \%$ ) than for wives of junior enlisted personnel (59\% to $78 \%$ ) or of NCOs (63\% to $90 \%)$.

A number of groups of wives did, for the most part, obtain the level of employment they desired. Newlyweds with college degrees, black newlyweds, mothers of preschoolers (90\%) or teens $(92 \%)$ who had been at their duty station for more than 4 years, wives with college degrees who had been at their duty station for more than 13 months, and wives of NCOs (90\%) or officers (94\%) who had been at their duty station for more than 4 years all reported congruence levels of $90 \%$ or higher or involuntary unemployment levels of less than ten percent.

Other groups were failing to achieve their desired levels of employment, with levels of $60 \%$ or lower (i.e., involuntary unemployment rates of $40 \%$ or greater). Those included Black wives with preschool children, wives of junior enlisted personnel with elementary school age children, wives without college degrees and less than 13 months at duty station (60\%), Black wives of junior enlisted (53\%) or wives had been at their installation for less than a year (59\%), and Black wives who had been at their installation station for less than a year.

Thus, it is not fair to the Army to suggest that all wives have problems with obtaining their desired employment status, but 
it is fair to say that some groups have much more difficulty than others. Generally, the problems center on wives who have been at their duty station less than 13 months who are also either junior enlisted or Black or have less than a college degree. At the same time, it is not correct that merely being Black, or not having a college degree, or being junior enlisted means, you will always have difficulty finding your desired employment status.

\section{Homemakers}

A fewer number of substantial interaction effects were observed for predicting homemaker status. The most dramatic effect occurred for life cycle and race. Homemaker status was low and consistently decreased over the life cycle (11/8/2/1\%) for Black wives while it varied for non-Black wives $(15 / 44 / 24 / 20)$ over the four stages of the family life cycle, as we defined it in this study. A second interaction effect occurred for life cycle and rank. Here the key was that wives of officers with preschool children were more often homemakers (61\%) than any other status, whereas among all the other eleven possible combinations, the percentages ranged between $12 \%$ (wives of junior enlisted personnel, newlywed and older life cycle stages) and no higher than 36 to $37 \%$ (wives of officers with elementary school age children and wives of NCOs with preschool children, respectively). A third interaction was noted for rank and years at duty station. Here, there were few differences with years for wives of junior enlisted personnel (21\% to 35\%) and for wives of NCOs (23\% to $28 \%$ ) but the differences were much larger for wives of officers, for whom homemaker status declined with years from $47 \%$ to $30 \%$. The unusual cells were for wives of officers who had been at the duty station less than 4 years, who were more likely to be homemakers than any other status.
Overall, the number and substance of interaction effects indicated that there are important variations to main effects when it comes to understanding which wives have which employment statuses in the Army. Simple theories, such as "If you are Black, you're not going to find a decent job" are unlikely to be true across all categories of rank, education, family life cycle, or years at duty station. The reality is more complex.

\section{Bivariate Employment Outcomes}

When we examined the mean scores on the six outcome variables as a function of employment status for all subjects, the most favorable outcomes occurred for the homemaker status, followed by full-time and part-time employment (which were usually equivalent), and not looking but wanting a job. The least favorable outcomes were always associated with looking for employment. However, there were different patterns for officers and enlisted personnel, as presented in Tables 8 and 9. For officers (Table 8) we found that the homemaker status was always associated with the most favorable outcomes, with effect sizes (compared to the next most favorable status) between 0.02 and 0.21 . However, the most notable effect sizes were found for the differences between labor force participation (measured by part-time employment, to be conservative) and looking for employment, effect sizes that ranged between 0.17 and 0.40 for the six outcomes. For enlisted personnel, the effect sizes associated with labor force participation were even larger, ranging from 0.15 to 0.48 . The strongest positive effect sizes for homemaker status were associated with outcomes in terms of marital satisfaction for enlisted personnel (ES $=0.12$ ). Tables 10 and 11 present comparable outcome data in terms of percentages.

Table 8: Six outcome variables as related to spouse employment status for officers (mean scores and standard deviations)

\begin{tabular}{|c|c|c|c|c|c|c|c|}
\hline \multicolumn{8}{|c|}{ Employment Status } \\
\hline Outcome Variables & Full-Time & Part-Time & Looking & Not Looking & Homemaker & df & $\mathbf{F}$ \\
\hline \multirow{2}{*}{ Personal Life Satisfaction } & 1.52 & 1.54 & 1.82 & 1.82 & 1.46 & 29,508 & 293.7 \\
\hline & $(0.59)$ & $(0.56)$ & $(0.7)$ & $(0.61)$ & $(0.53)$ & & \\
\hline \multirow{2}{*}{$\begin{array}{l}\text { Adjustment to the Demands } \\
\text { of Being an Army Family }\end{array}$} & 2.91 & 2.91 & 3.58 & 3.13 & 2.75 & 29,580 & 88.9 \\
\hline & 1.81 & 1.78 & 1.94 & 1.81 & 1.66 & & \\
\hline \multirow{2}{*}{$\begin{array}{l}\text { Satisfaction with Army's } \\
\text { Concern for Families }\end{array}$} & 8.26 & 8.24 & 8.64 & 8.4 & 7.94 & 29,243 & 47.7 \\
\hline & 2.52 & 2.37 & 2.38 & 2.44 & 2.51 & & \\
\hline \multirow{2}{*}{ Own Marital Satisfaction } & 1.89 & 2.09 & 2.53 & 2.5 & 1.86 & 29,357 & 103.7 \\
\hline & 1.7 & 1.87 & 2.16 & 2.2 & 1.78 & & \\
\hline \multirow{2}{*}{ Retention Intentions } & 2.95 & 2.76 & 3.24 & 2.91 & 2.64 & 29,187 & 103 \\
\hline & 1.43 & 1.41 & 1.61 & 1.54 & 1.29 & & \\
\hline \multirow{2}{*}{$\begin{array}{l}\text { Satisfaction with the Army } \\
\text { as a Way of Life }\end{array}$} & 7.22 & 7.21 & 7.88 & 7.21 & 6.65 & 29,189 & 119.6 \\
\hline & 2.81 & 2.63 & 2.92 & 2.58 & 2.57 & & \\
\hline
\end{tabular}

Note: All one-way analyses of variance have 4 degrees of freedom in the numerator; degrees shown in table are for the denominator. All $\mathrm{F}$ tests were significant, $p<.001$. Differences $>.05$ among mean scores are significant $(p<.05)$. 


\section{Psychology and Behavioral Science International Journal}

Table 9: Six outcome variables as related to spouse employment status for enlisted personnel (mean scores and standard deviations)

\begin{tabular}{|c|c|c|c|c|c|c|c|}
\hline \multicolumn{8}{|c|}{ Employment Status } \\
\hline Outcome Variables & Full-Time & Part-Time & Looking & Not Looking & Homemaker & df & $\mathbf{F}$ \\
\hline \multirow{2}{*}{ Personal Life Satisfaction } & 1.72 & 1.74 & 2.05 & 1.93 & 1.75 & 120,287 & $1,043.7$ \\
\hline & $(0.58)$ & $(0.60)$ & $(0.64)$ & $(0.63)$ & $(0.58)$ & & \\
\hline \multirow{2}{*}{$\begin{array}{l}\text { Adjustment to the Demands of } \\
\text { Being an Army Family }\end{array}$} & 3.39 & 3.46 & 4.60 & 3.94 & 3.23 & 121,198 & $1,233.8$ \\
\hline & $(2.08)$ & $(2.18)$ & $(2.58)$ & $(2.20)$ & $(1.83)$ & & \\
\hline \multirow{2}{*}{$\begin{array}{l}\text { Satisfaction with Army's Concern } \\
\text { for Families }\end{array}$} & 9.57 & 9.42 & 9.85 & 9.82 & 9.65 & 120,262 & 76.3 \\
\hline & $(2.72)$ & $(2.77)$ & $(2.83)$ & $(2.88)$ & $(2.91)$ & & \\
\hline \multirow{2}{*}{ Own Marital Satisfaction } & 2.67 & 2.58 & 3.24 & 2.76 & 2.26 & 120,413 & 438.7 \\
\hline & $(2.46)$ & $(2.46)$ & $(2.68)$ & $(2.48)$ & $(1.96)$ & & \\
\hline \multirow{2}{*}{ Retention Intentions } & 3.11 & 3.13 & 3.71 & 3.55 & 3.37 & 120,520 & 499.8 \\
\hline & $(1.66)$ & $(1.59)$ & $(1.73)$ & $(1.68)$ & $(1.63)$ & & \\
\hline \multirow{2}{*}{$\begin{array}{l}\text { Satisfaction with the Army as a } \\
\text { Way of Life }\end{array}$} & 7.75 & 7.66 & 8.44 & 8.07 & 7.78 & 119,619 & 230.7 \\
\hline & $(2.71)$ & $(2.80)$ & $(2.95)$ & $(2.83)$ & $(2.62)$ & & \\
\hline
\end{tabular}

Note: All one-way analyses of variance have 4 degrees of freedom in the numerator; degrees shown in table are for the denominator. All $F$ tests were significant, $p<.001$. Differences $>.02$ among mean scores are significant $(p<.05)$

Table 10: Six outcome variables as related to spouse employment status for officers (Percentages).

\begin{tabular}{|c|c|c|c|c|c|c|c|}
\hline \multicolumn{8}{|c|}{ Employment Status } \\
\hline Outcome Variables & Full-Time & Part-Time & Looking & Not Looking & HomeMaker & df & $\mathbf{X}^{2}$ \\
\hline Personal Life Satisfaction (\% Very Satisfied) & $53.0 \%$ & $49.2 \%$ & $34.2 \%$ & $29.6 \%$ & $54.9 \%$ & 12 & $1,771.0$ \\
\hline $\begin{array}{l}\text { Adjustment to the Demands of Being an } \\
\text { Army Family (\% Extremely Well Adjusted) }\end{array}$ & $50.3 \%$ & $49.1 \%$ & $36.5 \%$ & $43.4 \%$ & $53.1 \%$ & 40 & 903.7 \\
\hline $\begin{array}{l}\text { Satisfaction with Army's Concern for } \\
\text { Families (\% Satisfied or Very Satisfied) }\end{array}$ & $46.8 \%$ & $44.3 \%$ & $37.1 \%$ & $39.8 \%$ & $51.8 \%$ & 16 & 384.4 \\
\hline Own Marital Satisfaction (\% Most Satisfied) & $63.5 \%$ & $58.6 \%$ & $47.1 \%$ & $49.8 \%$ & $64.6 \%$ & 40 & $1,139.2$ \\
\hline $\begin{array}{l}\text { Retention Intentions (\% Stay Until } \\
\text { Retirement) }\end{array}$ & $66.5 \%$ & $73.8 \%$ & $57.3 \%$ & $71.1 \%$ & $77.5 \%$ & 12 & 573.1 \\
\hline $\begin{array}{l}\text { Satisfaction with the Army as a Way of Life } \\
\text { (\% Satisfied or Very Satisfied) }\end{array}$ & $64.9 \%$ & $64.7 \%$ & $51.4 \%$ & $63.6 \%$ & $73.4 \%$ & 16 & 733.8 \\
\hline
\end{tabular}

Note: Chi-square tests were performed with all categories of each variable, but percentages are reported for the most satisfied levels of the outcome variables in order to conserve space.

Table 11: Six outcome variables as related to spouse employment status for enlisted personnel (Percentages).

\begin{tabular}{|c|c|c|c|c|c|c|c|}
\hline \multicolumn{7}{|c|}{ Employment Status } \\
\hline Outcome Variables & Full-Time & Part-Time & Looking & Not Looking & Homemaker & df & $\mathbf{X}^{2}$ \\
\hline $\begin{array}{c}\text { Personal Life Satisfaction (\% Very } \\
\text { Satisfied) }\end{array}$ & $34.20 \%$ & $34.20 \%$ & $18.10 \%$ & $23.10 \%$ & $31.60 \%$ & 12 & $5,039.00$ \\
\hline $\begin{array}{c}\text { Adjustment to the Demands of Being } \\
\text { an Army Family (\% Extremely Well } \\
\text { Adjusted) }\end{array}$ & $39.80 \%$ & $39.50 \%$ & $21.90 \%$ & $27.60 \%$ & $37.30 \%$ & 40 & $8,020.10$ \\
\hline $\begin{array}{c}\text { Satisfaction with Army's Concern for } \\
\text { Families (\% Satisfied or Very Satisfied) }\end{array}$ & $31.50 \%$ & $28.00 \%$ & $21.30 \%$ & $25.30 \%$ & $30.10 \%$ & 16 & $1,731.00$ \\
\hline $\begin{array}{c}\text { Own Marital Satisfaction (\% Most } \\
\text { Satisfied) }\end{array}$ & $50.20 \%$ & $51.60 \%$ & $41.60 \%$ & $44.70 \%$ & $53.40 \%$ & 40 & $5,395.30$ \\
\hline $\begin{array}{c}\text { Retention Intentions (\% Stay Until } \\
\text { Retirement) }\end{array}$ & $69.70 \%$ & $64.00 \%$ & $46.20 \%$ & $52.80 \%$ & $58.80 \%$ & 12 & $3,458.5$ \\
\hline $\begin{array}{c}\text { Satisfaction with the Army as a Way of } \\
\text { Life (\% Satisfied or Very Satisfied) }\end{array}$ & $52.70 \%$ & $52.20 \%$ & $37.50 \%$ & $46.80 \%$ & $54.80 \%$ & 16 & $2,402.00$ \\
\hline
\end{tabular}

Note: Chi-square tests were performed with all categories of each variable, but percentages are reported for the most satisfied levels of the outcome variables in order to conserve space. 
Overall, it is clear that (a) involuntary unemployment is strongly associated with negative outcomes for civilian wives and that (b) freely chosen homemaker status is not associated with negative outcomes and is consistently associated with positive outcomes for the civilian wives of officers.

\section{Multivariate Employment Outcomes}

Employment status remained a significant predictor of personal life satisfaction, marital satisfaction, retention intentions, family adaptation, satisfaction with Army concern for families, and satisfaction with Army life after controlling for rank, race, family life cycle, years at duty station, and education. Employment status accounted for the most explained variance for personal life satisfaction and for marital satisfaction of any of the six variables used. It was the second-best predictor, after rank, for both family adaptation and for satisfaction with Army life. With respect to retention intentions and satisfaction with Army concern for families it was the third best predictor, after rank and family life cycle. In all cases, employment status was explained more variance than did race, education, or years at duty station. In the case of satisfaction with Army concern for families there was one two-way interaction (employment status with rank) that explained more variance than did the main effect of employment status. With respect to the rank by employment status interaction, it appeared that junior enlisted were not only the most dissatisfied with the Army's concern for families but those wives of junior enlisted who were employed full-time were even more dissatisfied (10.6) than those who were looking for work (10.1); at higher ranks, those who were employed full-time were much more satisfied than those who were looking for work.

With respect to marital satisfaction, there is a strong interaction effect between employment status and family life cycle. While there was a trend for greater satisfaction among wives at both ends of the family life cycle for all employment groups, the least variation in marital satisfaction occurred for homemakers, who were also more satisfied at each stage of the life cycle than any of the other groups with respect to marital satisfaction. The most dissatisfied of all groups were wives with preschool children who were looking for work and wives of elementary school age children who wanted to work but were not looking. The happiest of all groups were homemakers whose youngest children were teenagers or older.

Table 12: Satisfaction/dissatisfaction with employment and career opportunities, satisfaction with availability of affordable child care, and use of the military spouse preference program for employment as related to spouse employment status (percentages).

\begin{tabular}{|c|c|c|c|c|c|c|c|}
\hline \multicolumn{8}{|c|}{ Employment Status } \\
\hline $\begin{array}{l}\text { Outcome } \\
\text { Variables }\end{array}$ & Full-Time & Part-Time & Looking & Not Looking & Homemaker & df & $\mathrm{X}^{2}$ \\
\hline \multicolumn{8}{|c|}{ Satisfaction with Employment Opportunities } \\
\hline Satisfied & $45.1 \%$ & $35.2 \%$ & $15.6 \%$ & $17.7 \%$ & $34.4 \%$ & \multirow{2}{*}{16} & \multirow{2}{*}{$11,715.4$} \\
\hline Dissatisfied & $31.9 \%$ & $32.5 \%$ & $56.5 \%$ & $35.4 \%$ & $23.6 \%$ & & \\
\hline \multicolumn{8}{|c|}{ Satisfaction with Career Opportunities } \\
\hline Satisfied & $37.1 \%$ & $29.6 \%$ & $22.9 \%$ & $21.7 \%$ & $34.0 \%$ & \multirow{2}{*}{16} & \multirow{2}{*}{$4,439.6$} \\
\hline Dissatisfied & $34.8 \%$ & $38.0 \%$ & $48.0 \%$ & $39.4 \%$ & $27.8 \%$ & & \\
\hline \multicolumn{8}{|c|}{ Satisfaction with Availability of Affordable Daycare } \\
\hline Satisfied & $28.0 \%$ & $20.5 \%$ & $15.1 \%$ & $15.8 \%$ & $27.2 \%$ & \multirow{2}{*}{16} & \multirow{2}{*}{$3,360.2$} \\
\hline Dissatisfied & $49.5 \%$ & $55.3 \%$ & $57.7 \%$ & $52.5 \%$ & $37.2 \%$ & & \\
\hline \multicolumn{8}{|c|}{ Awareness and Use of the Spouse Preference Program } \\
\hline Not Aware & $23.8 \%$ & $16.3 \%$ & $10.1 \%$ & $16.8 \%$ & $33.1 \%$ & \multirow{3}{*}{8} & \multirow{3}{*}{$6,816.9$} \\
\hline $\begin{array}{l}\text { Aware, Not } \\
\text { Used }\end{array}$ & $28.7 \%$ & $19.8 \%$ & $9.2 \%$ & $11.5 \%$ & $30.8 \%$ & & \\
\hline Yes, Used It & $44.4 \%$ & $21.8 \%$ & $12.1 \%$ & $9.6 \%$ & $12.1 \%$ & & \\
\hline
\end{tabular}

Note: Chi-square tests were performed with all categories of each variable, but percentages are reported for the satisfied levels (very satisfied and satisfied) and the dissatisfied levels (very dissatisfied combined with dissatisfied) of the outcome variables in order to conserve space. Percentages sum across the rows for the military spouse preference program results to show how employment patterns differed as a function of awareness and use of the program but sum down the columns for the satisfaction variables to show how satisfaction varies as a function of employment status. All chi-square values are significant $(p<.001)$.

\section{Availability of Employment/Career Opportunities and Daycare}

The Army has attempted over the years to provide increased opportunities for spouses to find employment and to have adequate, affordable daycare, often on the installation itself. How well has the Army succeeded, according to its families? To in- vestigate these issues, we looked at satisfaction with employment opportunities and with long-term career opportunities as a function of employment status and then at satisfaction with availability of affordable daycare. Finally, we assessed the possible impact of the military spouse (employment) preference program, which was designed to increase employment oppor- 
tunities for Army spouses, as associated with actual spouse employment status. Results are presented in Table 12.

Many spouses were dissatisfied or very dissatisfied with employment opportunities and with long-term career opportunities. Overall, homemakers and those in the labor force were more often satisfied than dissatisfied with their employment and career opportunities whereas those who were involuntarily unemployed were consistently more likely to be dissatisfied than satisfied. The widest gap between percentages of satisfied and dissatisfied clearly occurred for the involuntarily unemployed with dissatisfaction levels between 35 and 57 percent. For homemakers, there was relatively little difference between the satisfaction levels for employment and for career opportunities. However, those in the labor force were more likely to report satisfaction with employment opportunities than with career opportunities whereas those who were involuntarily unemployed were more likely to report satisfaction with career opportunities than with employment opportunities. While those employed full-time are most satisfied with their opportunities and those still looking for paid work are least satisfied, there is a substantial amount of concern among all groups with respect to current and long-term employment opportunities.

The results are more dramatic for satisfaction with the availability of affordable daycare. Aside from homemakers, for whom the question may have been less relevant, the level of dissatisfaction ranges from $50 \%$ to $58 \%$ across all the other four groups. Satisfaction levels are lowest among those looking for work (15\%) and not looking but wanting work (16\%). While satisfaction levels are higher among those employed full-time (28\%), they are much lower than the satisfaction levels reported for employment and career opportunities as a wife of a soldier. The very high levels of dissatisfaction with availability of affordable daycare indicate that this issue is very important to most Army families, whose spouses are either in or hoping to be in the labor force.

Satisfaction with career opportunities, employment opportunities, and availability of daycare were correlated with the six outcome variables used in Tables 8-11, using zero-order Pearson correlations, in order to determine if the former three variables were relevant to important Army outcomes. The strongest correlations were obtained for satisfaction with the Army as a way of life $(.25<\mathrm{r}<.35)$ and for the satisfaction with the Army's concern for families scale $(.33<\mathrm{r}<.35)$ while the weakest correlations were obtained for marital satisfaction $(.10<\mathrm{r}<.12)$, but all eighteen correlations were statistically significant $(\mathrm{p}<.001)$. Correlations were recalculated for each of the five employment statuses, but no consistent and substantial variations were observed from the correlations obtained for the entire sample.

With respect to the military spouse preference program, the news is more encouraging perhaps. The percentages of those employed full-time and in the labor force increase substantially depending on one's experience with the program. Among those who have never heard of the program, only $24 \%$ are employed full-time and only $40 \%$ are in the labor force. In contrast, among those who have heard of the program, $29 \%$ are employed fulltime and $49 \%$ are in the labor force. Among those who have used the program, $44 \%$ are employed full-time and $66 \%$ are in the labor force. Involuntary unemployment is high among those who have never heard of the program (27\%) but somewhat lower among those who have heard of but never used the program (21\%) or among those who have used the program (22\%). The results exhibit a pattern that would be expected if the program was in fact accomplishing its objectives.

\section{Discussion}

With respect to our first objective, we did find that education, rank, time at duty station, family life cycle, and race did appear to be associated with levels of civilian spouse employment. Higher education appears to lend itself to a greater opportunity for labor force participation and for obtaining a desired employment status. Rank is also associated with employment status. Wives with soldiers of higher rank are more likely to realize their employment objectives; presumably, their higher military incomes and privileges allow them more freedom to have the type of current employment status that they prefer, whether in the labor force or as a homemaker. For enlisted personnel, it meant that wives of NCOs were more likely to be in the labor force than were the wives of junior enlisted personnel. Wives who had been located at their current installation longer were both more likely to be in the labor force and less likely to be involuntarily unemployed.

While previous scholars have discussed the role of children and employment, we are not aware of any who have investigated the role of the family life cycle - based on the ages of the youngest children in the military family. Families with preschool children reported the lowest levels of labor force participation, the highest percentages of homemakers, and the highest percentages of wives who are not working but wish they were. Overall, family life cycle explained the most variance in labor force participation of any of our independent variables. Race also played an important role, with Black wives reporting both some of the highest levels of labor force participation and, at the same time, some of the highest levels of involuntary unemployment (with very low percentages of homemakers). It appears that Black wives have labor force participation expectations that exceed those of most wives of other racial or ethnic backgrounds. However, we also found that main effects were often inadequate for helping us understand employment status among civilian wives of soldiers. The large number of substantial interaction effects observed betray any hope for simple solutions. Instead of sweeping problems with unemployment (e.g., junior enlisted wives just can't get any jobs!), we found pockets of difficulty that might be addressed more economically and effectively. 


\section{Acknowledgment}

This report is based on a revision of a paper presented at the Persons, Processes, and Places: Research on Families, Workplaces, and Communities Conference sponsored by the Business and Professional Women's Foundation in association with the Center for Families at Purdue University and the Alfred P. Sloan Foundation, San Francisco, February 9, 2002. Dr. Schumm is Professor of Applied Family Science, School of Family Studies and Human Services, College of Health and Human Services, Justin Hall, Kansas State University, 1700 Anderson Avenue, Manhattan, Kansas 66506-1403. Dr. Bell, now deceased, was a Research Psychologist with the U.S. Army Research Institute for Behavioral and Social Sciences, 5001 Eisenhower Avenue, Alexandria, Virginia 22333-5600. Dr. Fafara is a Senior Research Analyst, U. S. Army, 1500 Army Navy Drive, Arlington, Virginia.

\section{References}

1. Teachman, Jay D, Lucky M Tedrow, Kyle D Crowder (2000) The Changing Demography of America's Families. Journal of Marriage and the Family 62(4): 1234-1246.

2. Arendell Terry (2000) Conceiving and Investigating Motherhood: The Decade's Scholarship. Journal of Marriage and the Family 62(4): 11921207.

3. Perry Jenkins, Maureen, Rena L Repetti, Ann C Crouter (2000) Work and Family in the 1990s. Journal of Marriage and the Family 62(4): 981-998.

4. Hoffman, Lois Wladis (2000) Maternal Employment: Effects of Social Context. In: Ronald D Taylor, Michael C Wang (eds.), Resilience Across Contexts: Family, Work, Culture, and Community. Lawrence Erlbaum Associates, Publishers: Mahwah, New Jersey, pp. 147-176.

5. White, Lynn, Stacy J Rogers (2000) Economic Circumstances and Family Outcomes: A Review of the 1990s. Journal of Marriage and the Family 62(4): 1035-1051.

6. Greenhaus Jeffrey H, Saroj Parasuraman (1999) Research on Work, Family, and Gender: Current Status and Future Direction. In: Gary
N Powell (ed.), Handbook of Gender \& Work, Sage Publications: Thousand Oaks, California pp. 391-412.

7. Conger RD, Rueter MA, Glen H Elder (1999) Couple Resilience to Economic Pressure. J Pers Soc Psychol 76(1): 54-71.

8. Davidson, Marilyn J, Sandra Fielden (1999) Stress and the Working Woman. In: Gary N Powell (ed.), Handbook of Gender \& Work, Sage Publications: Thousand Oaks, California pp. 413-426.

9. Voydanoff Patricia (2002) Linkages between the Work-Family Interface and Work, Family, and Individual Outcomes: An Integrative Model. Journal of Family Issues 23(1): 138-164.

10. Grzywacz, Joseph G, David M, Almeida, Daniel A Mc Donald (2002) Work-family Spillover and Daily Reports of Work and Family Stress in the Adult Labor Force. Family Relations 51(1): 28-36.

11. Black WG (1995) Military families. In: David Levinson (ed.), Encyclopedia of Marriage and the Family. MacMillan Library Reference USA: New York pp. 500-505.

12. Russo, Theresa J, Lea M Dougherty, James A Martin (2000) Military Spouse Employment: Challenges and Opportunities. In: James A Martin, Leora N Rosen, Linette R Sparacino (eds.), The Military Family: A Practice Guide for Human Service Providers. Praeger, United Nations pp. 87-102.

13. Pittman Joe F (1994) Work/Family Fit as a Mediator of Work Factors on Marital Tension: Evidence from the Interface of Greedy Institutions. Human Relations 47(2): 183-209.

14. Segal Mady W (1986) The Military and the Family as Greedy Institutions. Armed Forces \& Society 13(1): 9-38.

15. Bowen Gary L (1989) Family Factors and Member Retention: A Key Relationship in the Work and Family Equation. In: Gary L Bowen, Dennis K Orthner (eds.), The Organization Family: Work and Family Linkages in the U. S. Military. Praeger, New York p. 37-57.

16. Bowen Gary L (1987) Wives employment status and marital adjustment in military families. Psychol Rep 61(2): 467-474.

17. Sebenick Carole W (1998) The Career Development and General WellBeing of Military Officer's Wives. (Unpublished Doctoral Dissertation, University of Maryland), Dissertation Abstracts International 60(3-B): 1315.

\section{Your next submission with Juniper Publishers will reach you the below assets}

- Quality Editorial service

- Swift Peer Review

- Reprints availability

- E-prints Service

- Manuscript Podcast for convenient understanding

- Global attainment for your research

- Manuscript accessibility in different formats

( Pdf, E-pub, Full Text, Audio)

- Unceasing customer service

Track the below URL for one-step submission

https://juniperpublishers.com/online-submission.php 